\title{
HIP-HOP CULTURE REPRESENTATION IN TELEVISION ADVERTISING
}

\author{
Oleh: \\ Kristanto Setiawan \\ Dyah Nurul Maliki ${ }^{1)}$
}

\begin{abstract}
This research used framing analysis by Gamson and Modigliani. This research utilized framing analysis to tell storyline of Nano-Nano Chewy Advertising. Framing Analysis by Gamson and Modigliani has been using to get hip-hop culture representative by using framing devices and reasoning devices element. This research using descriptive qualitative approach. Technique Data collecting in this research is documentation, participant passive observation, and interview. Data collecting in this research is framing analysis by Gamson and Modigliani.

The result of research showing that there is a hip-hop culture representative in Nano-Nano Chewy Advertising. The representative is showing by rapping, breakdance, grafiti and fashion element. NanoNano Chewy Advertising have an objective to create cool, fun, and cheeful association. This association was developed specially for Nano-Nano target market which is an teenager.

This research tell that there is a functional and emotional benefit from Nano-Nano Chewy product. The Creative concept that looks cheerfull is associates with the brand tagline "Rame Rasanya". This Advertising was create to maintain Nano-Nano top of mind brand awareness.
\end{abstract}

Keywords: Framing, Hip-hop, Representation, Advertising, Nano-Nano Chewy.

Teori yang digunakan dalam penelitian ini adalah analisis framing Gamson dan Modigliani. Framing digunakan untuk melakukan pembingkaian terhadap iklan Nano-Nano Chewy. Analisis framing Gamson dan Modigliani digunakan untuk menemukan representasi budaya hip-hop melalui penggunaan framing devices serta reasoning devices. Pendekatan penelitian yang digunakan adalah kualitatif deskriptif. Teknik pengumpulan data dilakukan dengan studi pustaka, observasi partisipasi pasif, dan wawancara. Teknik analisis data yang digunakan adalah analisis framing Gamson dan Modigliani

Hasil penelitian ini menunjukan adanya representasi budaya hip-hop melalui elemen rap,breakdance, grafiti serta gaya busana. Iklan Nano-Nano Chewy memiliki tujuan untuk membentuk asosiasi yang keren, asik, dan rame. Asosiasi tersebut ditunjukan untuk target market Nano-Nano yaitu remaja Indonesia.

Penelitian ini juga menemukan bahwa iklan ini menyampaikan tentang functional benefit serta emotional benefit produk Nano-Nano Chewy. Konsep iklan yang terlihat rame juga sejalan dengan tagline Nano-Nano yaitu "Rame Rasanya". Iklan ini juga dibuat dengan tujuan untuk mempertahankan brand awareness Nano-Nano tetap dalam tingkatan top of mind.

Kata kunci: Framing, Hip-hop, Representasi, Iklan, Nano-Nano Chewy.

Program Studi Ilmu Komunikasi Institut Bisnis dan Informatika Kwik Kian Gie. Jl. Yos Sudarso Kav.87, Sunter, Jakarta Utara 14350. q2tjokro@gmail.com

Program Studi Ilmu Komunikasi - Institut Bisnis dan Informatika Kwik Kian Gie 


\section{INTRODUCTION}

Popular culture emerged along with the times supported by advances in information and communication technology. Popular culture is also always changing and appears uniquely in various places and times. Various things related to popular culture can attract a wider spectrum in society.

Hip-hop culture originally emerged as a black movement in the United States against white resistance in 1974. The existence of separation of skin color or what is known as discrimination is one of the major upheavals in several states of the United States. Hip-hop music in Indonesia began to slowly rise, starting with the presence of social media and various video sharing sites such as Youtube.

The use of social networks such as Youtube is more appropriate to target adolescent consumers. Various brands must take advantage of this new opportunity to be able to communicate their marketing campaigns through digital advertisements on video sharing sites such as Youtube. The existence of hip-hop culture is not only in the music industry, but also exists in a form of marketing communication that utilizes mass media as the main media, namely advertising.

Nano - Nano is a well-known hard candy producer in Indonesia. In communicating its products through advertisements, Nano-Nano sees an opportunity to use Youtube as the main medium, especially for advertisements in digital form. Advertising is used to provide awareness to consumers of various new products issued by the company. One of them is the Chewy Nano-Nano product.

Nano - Nano Chewy is a candy that is classified as a candy with a soft texture (soft candy). The main target of this product is teenagers. Nano - Nano made Nano - Nano Chewy due to a shift in consumer appetite for favoring candy with a soft texture compared to a solid texture. In addition, there is a shift in taste where consumers prefer sweets that have a sweet taste rather than a sour taste. The use of hip-hop culture as the main concept of Nano - Nano Chewy's advertisement is also interesting to study by researchers in seeing that the representation of hip-hop culture is actually associated with an icon, in this case the youtuber SkinnyIndonesian24.

This research uses popular culture theory as the main theory which can provide a clearer understanding of the hip-hop culture that appears in the Nano-Nano Chewy commercial. This research is also included in qualitative research, especially qualitative descriptive. The data analysis method used by researchers in this study was Gamson and Modigliani framing analysis.

To achieve the research objectives in the study "Gamson and Modigliani Framing Analysis Related to Hip-Hop Cultural Studies in Nano Advertising - Nano Chewy" the author divides the main objectives of the study in terms of the main focus which can be seen as follows:

1. To find out the framing devices of hip-hop culture in the Nano - Nano Chewy commercial.

2. To find out the reasoning devices of hip-hop culture in Nano - Nano Chewy's commercial.

\section{REVIEW THE LIBRARY}

According to Mulyana (2008: 83) states that "Mass communication is communication that uses mass media, both printed (newspapers and magazines) or electronic (radio and television), relatively expensive, which is managed by an institution or institutionalized person aimed at a large number of people who are spread over many places, anonymous and heterogeneous".

The concept of mass communication is actually inseparable from the concept of mass itself, which according to McQuail (2011: 61) states that: "The concept of mass, which consists of a large group of people, has similar content, is generally perceived as negative, has no internal 
structure or order and is a reflection of the wider mass society." Mass is a major part of the concept of mass communication.

According to Morrisan (2010: 17) Advertising can be defined as any form of nonpersonal communication about an organization, product, service, or idea paid for by a known sponsor. The purpose of being paid in this definition shows the fact that space or time for an advertising message generally must be purchased.

The meaning of the word non-personal means an advertisement involving the mass media ( $\mathrm{TV}$, radio, magazines and newspapers) which can send messages to a large number of groups of individuals at the same time. As such, the nonpersonal nature of advertising means that there is generally no opportunity for immediate feedback from the recipient of the message. Before sending advertising messages, advertisers must really consider how the audience will interpret and respond to the intended advertising message.

According to Eriyanto (2012: 78), Framing in William Gamson and Andre Modigliani is a way of telling stories or groups of ideas organized in such a way and presenting the construction of the meaning of events related to the object of a discourse. The way of telling stories is formed in a package (package).

Core frame (central idea) basically contains core elements to provide a relevant meaning to the event, and directs the meaning of the issue - which is constructed by condensing symbols (symbols that are "compressed"). Condensing symbols are the result of examining the interaction of symbolic devices (framing devices and reasoning devices) as a basis for using perspective. Symbols in discourse appear transparent if they infiltrate a meaningful device capable of acting as a guide to replace something else.

More details, Framing devices in Gamson and Modigliani Framing consist of:

a. Metaphors are understood as a way of transferring meaning by relating two facts through analogy or using figures of speech by using words such as, like, bak, as, for example, and like. Metaphor is a kind of comparative language style that is the shortest, densest, and neatly arranged. In it are seen two ideas, one is reality, something that is thought about, which becomes the object, and the other is a comparison to the earlier reality and we replace the latter to become earlier.

b. Exemplars package certain facts in depth so that one side has more weight of meaning to be used as a reference / lesson. Its position is to complement the core frame of the news unit to justify perspective.

c. Catchphrases, terms, formations of words, or phrases that are typical of facts that refer to certain thoughts or spirits. In the news text catchphrases manifest in the form of jargon, slogans, or slogans.

d. Depictions, depictions of facts using words, terms, and connotative sentences so that the audience is directed to a certain image. The assumption is that the use of special words is intended to arouse prejudice, mislead thoughts and actions, and be effective as a form of political action. Depictions can take the form of stigmatization, euphemism, and acronimization.

e. Visual Images, the use of photos, diagrams, graphics, tables, cartoons, and the like to express an impression. For example, attention or rejection, raised - reduced, bolded or tilted, as well as color representation. Visual images are very natural, very representative of reality, which makes the message ideology closely related to the audience.

Reasoning Devices in Gamson and Modigliani framing:

a. Roots (casual analysis) justifies the issue by connecting one or more objects that are considered to be the cause of the emergence or occurrence of other things. The goal is to justify the conclusion of facts based on the causal relationship that is described or disclosed. 
b. Appeals to principle, thoughts, principles, moral claims as arguments to justify building news in the form of proverbs, folk tales, myths, doctrines, teachings, and the like.

Popular culture according to McQuail (2011: 128) is a cross product of numerous and relentless efforts to express in a contemporary way that aims to reach people and capture the market, and an active demand from people called Fiske (1987) as meaning and enjoyment.

According to Adhe (2005: 3), Hip-hop is an art form that includes DJ-ing (cutting and scartching), MC-ing or rapping, breakdancing, and graffiti art. As we know today, these art forms began in the South Bronx area, New York, in the mid-1970s. DJ-ing (cuttin 'and scratchin') is the manipulation of a recording of a specific groove to produce strange noises. MC-ing or Rapping has its roots in the Jamaican art form known as toasting.

Rap is a form of expression that finds its roots in ancient African culture and oral traditions. Breakdancing, a colorful and acrobatic dance style that includes headspin and backspin has its roots in the African martial art form known as capoeta. Graffiti or graffiti is one of the four elements in hip-hop culture. Graffiti started out as an underground urban art that was prominently displayed in public areas, usually on the walls of buildings. Graffiti is used by townspeople to express social and political commentary, much as gangs usually mention the areas under their control.

\section{RESEARCH METHODS}

The research subject in this study was Nano - Nano Chewy advertisement with a duration of 60 seconds. The reason the researchers used the Nano-Nano Chewy advertisement with a duration of 60 seconds is because the 30 second version that is on TV does not really show a representation of hip-hop culture, both in terms of the use of various words in the jingle and related visual images. This ad was created by advertising agency Matari for the launch of the Nano-Nano Chewy product.

The approach used in this research is descriptive qualitative. Primary data were obtained from research subjects, namely Nano Nano Chewy advertisement with a duration of 60 seconds. In this study, secondary data is a variety of visual materials obtained from data available on the internet, videos, and books.

The data collection techniques used by researchers are literature study, participatory observation (passive participation), and researchers conduct interviews with three informants who work at the advertising agency Matari. The three informants are Leli Nurlalili as Copywriter. Seno Pindiatko as Art Director. Andriani Lumankun Soetoto who is Creative Director.

The three informants are a team that works and is responsible for making Chewy's NanoNano ad. This research was conducted using the framing analysis method. In this framing analysis, researchers used a framing device method consisting of metaphors, exemplars, catchphrases, depictions and visual images as well as a reasoning tool consisting of roots and appeals to principle popularized by William A Gamson and Andre Modigliani.

\section{RESULTS AND DISCUSSION}

The research results from the analysis and discussion of Gamson and Modigliani's framing related to the representation of hip-hop culture at each frame have different representations from one another. Of the five frames analyzed, all frames show a representation of hip-hop culture in the Nano-Nano Chewy commercial. However, not all representations of hip-hop culture can be found in every frame. There are several elements in the Gamson and Modigliani framing that are not in a certain frame. The research results 
obtained from the analysis and discussion of each frame can be described as follows.

The use of framing devices in Chewy's Nano-Nano advertisements can be seen from several elements which include metaphors, exemplars, catchphrases, depictions and visual images. Visual Images are one of the elements of framing devices that appear dominant in the Nano-Nano Chewy advertisement. Other elements of framing devices can be found in the following elaboration.

The core frame in Chewy's Nano-Nano commercial is more about the representation of hip-hop culture that applies universally. The cultural representation of hip-hop is divided into breakdancing, rap, graffiti and fashion. Fashion is a form of the hip-hop culture industry that is related to fashion trends. Fashion trends will change as they are not consumed by society. What is worn by an individual is a form of representation about identity / personality. All the attributes inherent in a person indirectly show the formation of an image for himself in the eyes of others. Various styles of dress tend to be determined by individual personal preferences. This is also supported by the statement of informant Leli: "Personal Style". Personal style in question is a style of dress created by the individual concerned, usually based on his love for what is appropriate and appropriate for him to wear and can also grow his own image of himself.

The condensing symbol in the Nano-Nano Chewy advertisement talks more about the representation of SkinnyIndonesian24 as a Youtuber as well as an influencer. This is also used by the Nano-Nano to make them the brand ambassador for Chewy's Nano-Nano. The use of Youtuber SkinnyIndonesian24 as the brand ambassador for Nano-Nano Chewy is also related to the target product target, namely Indonesian youth.

An element of framing devices that is no less important is the metaphors. The metaphors in this advertisement are more focused on the use of various words such as a lot, crowded, flavor, cool, and chewy. These words actually have something to do with and to do with the association that Nano-Nano wants to form with Chewy's NanoNano product.

Exemplars in this ad are more focused on conveying the functional benefits of Chewy's Nano-Nano product by repeating words and using supporting visual images. Understanding functional benefits according to the opinion of the informant Andriani: "Benefits received by consumers from product excellence". This functional benefit is seen in Chewy's repeated words to give the understanding that the NanoNano has candy with a soft texture.

Catchphrases in this advertisement actually communicate more positive things. This positive thing can be seen from the description of Chewy's Nano-Nano product, which is a product that has a fun, fun, lively and cheerful association. The use of SkinnyIndonesian24 as a brand ambassador gives a certain spirit to the young generation of Indonesia to remain in a cheerful and happy atmosphere. This is actually in line with the NanoNano's main tagline, which is "the taste".

The depictions in this advertisement communicate more about the expectations to be formed from Chewy's Nano-Nano products. The expectations referred to are candy products that match the characteristics of Indonesian youth. Teenagers generally like candy with various flavors and have a soft texture like the one in Nano-Nano Chewy.

The discussion on reasoning devices in Chewy's Nano-Nano advertisement includes roots and appeals to the principle which can be seen in the following description. The roots in this advertisement are more directed towards hip-hop culture as a form of popular culture that has become a cultural industry. This can be seen from the many brands that use the concept of hip-hop to approach their target targets, which are mainly teenagers or generation $\mathrm{Y}$. One of the most effective ways is to use a well-known Youtuber like SkinnyIndonesian24. 
Nano-Nano uses SkinnyIndonesian24 in communicating the famous Chewy Nano-Nano product variants in various flavors with a "busy" advertising concept. The crowded concept in the Nano-Nano Chewy ad is derived from its main tagline, "Rame Taste". In translating this concept, the Nano-Nano depicts hip-hop culture as a universal culture. Universal is a description of things that apply in general. One of them is by using the term cultural diversity. Indonesia's cultural diversity can be seen from various ethnic groups with different cultures.

Appeals to the principle in this advertisement are that the roots of hip-hop culture are basically a form of communication to convey criticism of various social policies that are troubling the community. Nowadays, the delivery of this criticism can be in the form of memes. Memes are now used as a means of making satire related to social problems in society in the form of jokes. The satire in this meme is an attempt to build critical thinking to express opinions on social media related to various problems in society.

Hip-hop culture is now beginning to stray from its roots as a form of social criticism. This is reflected in the hip-hop cultural content on the YouTube site. Hip-hop cultural influencers such as SkinnyIndonesian24 are now only focused on creating content about the growing trends on social media. There is no content that has a focus on raising social problems in society such as corruption, poverty, and others. Content creators only care about their popularity. Video content on Youtube seems to be their main source of income. Not infrequently, they attract the attention of an audience dominated by teenagers by creating content that destroys the morals and ethics of Indonesia's young generation in pursuit of popularity.

Researchers also found various research results that were not related to the representation of hip-hop culture according to Gamson and Modigliani's framing. The results of this study were obtained from interviews with informants and the assumptions of the researchers themselves. The results of this study can be described as follows.

Advertising through mass media (in this case television) can make a product popular. This is because television can make a product very popular so that it is profitable for the product manufacturer. Ads that are made are also becoming increasingly popular depending on the reaction of the ad audience. If the ad is very annoying or very impressive, then it is not uncommon for it to be something that everyone is talking about or the term is now known as viral. Nano-Nano makes use of advertisements on television not only to introduce Chewy's NanoNano products, but more to maintain the existence of their brand awareness so that it remains at the top of mind level.

Popular culture in this case is hip-hop culture produced and utilized by certain companies to provide maximum profit for them. This advantage can be seen in the various products that are produced to fulfill and support the existence of the hip-hop culture. One of them is in the fashion industry.

The fashion style or fashion that develops in Indonesia is actually much influenced by the role of public figures, in this case YouTubers. Youtuber is now one of the most popular role models for Indonesian teenagers. The role model in question is the main reference in behavior, clothing style, and others. According to an informant Seno, regarding hip-hop cultural products, "There are many forms. Not only music, there are shoes, clothes ... " An explanation of the opinion of informant Seno can be seen in the following discussion.

A product of hip-hop culture that plays a more visible role in Indonesia is the use of various clothes related to T-shirts, hoodies and sweaters from various well-known brands such as Puma, Adidas, and others. In addition, there is a trend of sneakers used by Indonesian teenagers in everyday life. Sneakers are also a form of trend 
that is used by some hip-hop musicians to support their various performances.

Sneakers are used to support their appearance because they have flexibility that can provide flexibility in moving on stage. But now, sneakers are not only used as footwear, but have become a must-have product for teenagers. Teens will feel cool and up to date if they follow what's trending. Sneakers are also one of the products that fall into the prestige category. This is evidenced by the emergence of sneakers with limited variants and at fantastic prices.

The tendency to follow the fashion styles worn by YouTubers has also led to the phenomenon of hedonism among Indonesian teenagers. Hedonism is a behavior that spends money to buy products that are not a necessity for those concerned. In addition, teenagers also tend to look for affordable brand alternatives related to the various products used by their idols. It is not uncommon that they are willing to use fake products to be seen wearing the same products as their idols.

Researchers also found that the fashion / clothing style used in this advertisement was only as a complement. According to informant Seno's opinion: "We don't really focus on the fashion. It's not too unique. Fashion is just a complement. " In Chewy's Nano-Nano ad, the thing to watch out for is the product. Other elements such as fashion are only supporting elements to show the representation you want to form.

The use of fashion in the advertisement of Chewy's Nano-Nano is more widely adopted from the current trend. This is also in line with the statement of informant Andriani: "We adopt our talents by wearing clothes / fashion that are the best." Meanwhile, informant Seno complements informant Andriani's statement with the statement: "The information is from outside artists. The artist is Drake...". The suitability of using trends in fashion styles is also tailored to the target consumers of Nano-Nano Chewy based on the lifestyle of Indonesian youth.
Researchers also found that the use of clothing styles in this advertisement adjusts to several aspects outside the advertising concept. One of them is brand color. The brand color referred to is the iconic color that characterizes the brand, in this case the Nano-Nano, which is famous for its orange and yellow colors. Informant Leli also expressed this: "For example, the relationship with TVC has many considerations. Like for example brand color. We have to compromise with that too... "The use of various colors in the clothes worn by talents must also be different and not visible so that the advertised products can be easily seen by ad viewers.

In expressing themselves, everyone has their own way. One of them is by writing their aspirations in order to attract people's attention on urban walls. This is known as graffiti art. The emergence of graffiti as a means of selfexpression shows the growing concern of adolescents in seeing social phenomena that are troubling society. The growing awareness to write criticism of the government in making policies for society shows that the younger generation is not a generation that does not care about anything other than themselves.

Graffiti is not just an act of defiling urban walls with the aim of attracting people's attention. Graffiti is a form of protest by several people regarding various political and social policies. Grafiti is also an action to gather public support to realize that they have to see that policies issued by the government do not necessarily benefit all levels of society.

However, the fact is that graffiti is now considered a criminal act. This is in line with the notion of vandalism where it is prohibited to scribble a building because it can damage the beauty of the building. This action also discourages artists from sharing their expressions regarding the various sanctions issued by the government against graffiti. Graffiti can also be detrimental to certain parties, one of which is the 
government. The government needs to pay various costs to clean the graffiti on urban walls.

One of the elements in hip-hop music that can make other people feel interested is the rapping part, also known as rap. Rap is a way of singing and reciting song lyrics quickly according to the rhythm / beat of the song. Rap is seen as one of the things that look cool by teenagers. This is actually also in line with the purpose of rap itself, which is to feel good about other people's views. The younger generation is more interested in learning rap and doing it by covering various famous hip-hop songs so that they look cooler and up to date.

The rapping element can also be found in the use of English in Indonesia's younger generation. The use of English combined with Indonesian is also a form of communication that has begun to shift and is not in accordance with the correct Indonesian rules. The way of communication of the young Indonesian generation, who have started using various strange terms or commonly known as slang, can only be understood by certain groups. Not everyone can understand the meaning of using the slang language so that it can make it difficult to convey the message to the recipient of the message.

Researchers also found that the word "taste" in Chewy's Nano-Nano advertisement has a variety of meanings. The word "taste" can be related to Chewy's Nano-Nano product, but "taste" here has many meanings, as informant Leli stated: "Feeling happy, feeling meeting friends, feeling exciting, feeling the Nano-Nano itself." The word "taste" also represents the Nano-Nano Chewy product variant which does have a "crowded" impression because it consists of sweet, sour and salty flavors.

The "crowded" concept in Chewy's NanoNano advertisement is also based on the functional benefits and emotional benefits of the Nano-Nano brand. According to Andriani's informant, the statement regarding functional benefits is: "Benefits received by consumers from product excellence." Meanwhile, emotional benefits are: "Benefits that are felt emotionally by consumers." The functional benefits of the NanoNano Chewy product are the soft candy texture and various flavors that are tailored to the tastes of the younger generation who are the target market. The emotional benefit that Chewy NanoNano wants to create is that its products do show a cool, fun, exciting, lively, and cool impression.

The main execution of Chewy's Nano-Nano ad is also primarily based on the FUNK concept in Matari Ad. FUNK stands for Focus, Unique, Nendang, and Klop. Informant Andriani stated the relationship between the FUNK concept and Chewy's Nano-Nano advertisement in the following description: "The main focus. In all the execution was busy. It is good at translating the talents, translating the clothes, translating into the music, translating into colors. Unique. We're looking for something unique. Nendang that is related to consumers. Matches that match the audience." This can also be seen from the execution of advertisements which focus on describing a "crowded" atmosphere with various talents, settings, fashion styles, music, and others. The compatibility between the advertising concept and Chewy's Nano-Nano products can form a positive association that affects the NanoNano brand itself. This is actually evident from the existence of the Nano-Nano brand awareness which still reaches the top of mind level in the confectionary or confectionery industry.

\section{CONCLUSION}

This research answers the research objectives through the use of framing devices and reasoning devices to obtain a representation of hip-hop culture in Nano-Nano Chewy's advertisement. The Core Frame in this study answers the representation of hip-hop culture in terms of breakdancing, rap, graffiti, and fashion styles. This representation is also related to the trend of popular culture that is being loved by Indonesian youth. The condensing symbol in this 
study answers the representation of hip-hop culture by using Youtuber SkinnyIndonesian24 as the brand ambassador for Nano-Nano Chewy. SkinnyIndonesian24 as one of the influencers has a big influence, especially with regard to the Nano-Nano target consumer who is dominated by Indonesian teenagers.

There are various words used in this advertisement, such as a lot, crowded, flavor, cool, and chewy. These words fall into the category of metaphors. Chewy is the most important word among other words because it communicates the functional benefits of Chewy's Nano-Nano product which has a soft, chewy texture, and various flavors such as Blueberry Lime, Original Skin Orange, and Soursop Mango. The words flavor, lots, cool, and fun further clarify the emotional benefits of Chewy's NanoNano products. The emphasis on the word cool in the Nano-Nano Chewy advertisement aims to provide a feeling of coolness, fun and slang to Indonesian teenagers.

Exemplars in this advertisement attract the attention of viewers to pay attention to advertisements with repetitive words that fall into the metaphors category. The repetition of this word aims to clarify the advertising message and instill memories in the minds of consumers. The catchphrases in this advertisement respond to representations of hip-hop culture by forming associations that are fun, exciting, lively and cheerful, which also illustrate the characteristics of Indonesian youth. Depictions in this advertisement hopes that the advertisement for Chewy's Nano-Nano product can match the expectations of the Indonesian young generation who like products with various flavors, namely sweet, salty, and sour. The role of Visual Images only helps to clarify the representation of hip-hop culture in terms of the use of fashion styles, supportive talents, location settings, and so on.

Roots in this ad discusses more about the Nano-Nano product concept, namely "crowded". This concept is actually in line with the meaning of diversity for the Indonesian people. Hip-hop culture as a form of popular culture can be enjoyed by all Indonesian people regardless of certain ethnic groups / ethnicities.

Appeals to the principle in this advertisement show a representation of hip-hop culture in the real world that is different from the actual roots of hip-hop culture. Hip-hop culture basically has the aim of providing criticism of various social problems in society. Now, this role has begun to change with the presence of the YouTube video sharing site. Hip-hop cultural influencers such as Youtuber SkinnyIndonesian24 do not convey their forms of criticism of social phenomena that exist in society. They only focus on delivering content that discusses problems that commonly occur among Indonesian teenagers, regarding love, lifestyle, and others. The content they create is only for the sake of popularity.

Chewy's Nano-Nano advertisement is basically created to maintain the Nano-Nano's brand awareness to stay at the top of mind level. Advertising is used because it is able to reach a large audience and can form an image related to the product. The image that you want to create in this product is in accordance with its tagline, which is "Its taste."

This study still has not found a representation of hip-hop culture in terms of a broad scope and focus on discussing the culture itself. This research is still related to advertising that uses hip-hop culture as its main concept. Researchers hope that this research can become a reference for research developments that will discuss topics related to hip-hop culture, especially its use in television commercials. Researchers also found other things outside of hip-hop cultural framing that can be used as references to become further research topics. Among them are functional benefits and emotional benefits in a product and the application of the Matari Ad ad execution concept which adheres to FUNK (Focus, Unique, Nendang, and Klop). 
The researcher hopes that this research can also be used as an evaluation material for NanoNano regarding the representation of hip-hop culture which is related to the Nano-Nano Chewy product. The hip-hop culture that is now attached to many YouTubers, one of which is SkinnyIndonesian24, is expected to help NanoNano Chewy to become known as the candy of young people. Planting the mindset in the minds of the target audience that Nano-Nano is a candy product that has many flavors also fits the tagline "Taste-like".

This research is also useful to see the use of framing related to Nano-Nano Chewy's advertisement in relation to hip-hop culture in Indonesia. Nano-Nano can also continue to innovate by presenting products according to the tastes of the Indonesian people and bringing up the latest and up to date trends as the main concept of advertising in products that will be launched next.

\section{REFERENCES}

Adhe, 2005. Hip - Hop: Perlawanan dari Ghetto, Yogyakarta: Alinea.

Eriyanto. 2012. Analisis Framing: Konstruksi, Ideologi, dan Politik Media Cetakan Ketujuh,Yogyakarta: Lkis Printing Cemerlang.

Garincha, Arthur. 2017. Fashion dalam Hip Hop sebagai Identitas, diakses 15 November 2017 pukul 13.30 WIB, https://qubicle.id/story/fashion-dalam-hip-hopsebagai-identitas.

Kriyantono, Rachmat. 2010. Teknik Praktis Riset Komunikasi: Disertai Contoh Praktis Riset Media, Public Relations, Advertising, Komunikasi Organisasi, Komunikasi Pemasaran, Jakarta: Kencana Prenada Media Group.

McQuail, Denis. 2011. Teori Komunikasi Massa McQuail Buku 1: Edisi 6, Jakarta: Salemba Humanika.
Morissan. 2010. Periklanan: Komunikasi Pemasaran Terpadu, Jakarta: Kencana Prenada Media Group.

Mulyana, Deddy. 2008. Ilmu Komunikasi Suatu Pengantar, Bandung:Remaja Rosdakarya.

Rani. 2013. Sosiologi Budaya, diakses 21 Oktober 2017 pukul 11.00 WIB, https://www.google.com/amp/s/sosiologibudaya. wordpress.com/2013/04/25/budaya-populer$\underline{2 / a m p /}$

Sebastian, Evan. 2017. Sudut Pandang Perspektif Millenial, diakses 5 November 2017 pukul 22.00

WIB, https://rumahmillennials.com/2017/04/20/sudutpandang-perspektif-antar-millennial/

Sobur, Alex. 2012. Analisis Teks Media Suatu Pengantar Untuk Analisis Wacana, Analisis Semiotik, dan Analisis Framing,Bandung: Remaja Rosdakarya

Strinati, Dominic. 2016. Popular Culture: Pengantar Menuju Teori Budaya Populer, Yogyakarta: Narasi.

Stute, Dennis. 2017. Diskriminasi Kulit Hitam, diakses 22 Oktober 2017 pukul 14.00 WIB, http://m.dw.com/id/diskriminasi-kulithitam-di-amerika-serikat/g-18091393

Susanti, Lina. 2011. Penampilan adalah Gambaran Diri, diakses 8 November 2017 pukul 10.00 WIB, http://mengukirfikir.blogspot.co.id/2011/04/pena mpilan-adalah-gambaran-diri.html?m=1 